\title{
Prevalence and antimicrobial resistance of Bacillus cereus isolated from beef products in Egypt
}

\author{
Reyad Shawish ${ }^{1}$ and Reda Tarabees ${ }^{2, *}$ \\ ${ }^{l}$ Department of Food Hygiene and Control, Faculty of Veterinary Medicine, University of Sadat City, Sadat City, \\ Egypt \\ ${ }^{2}$ Department of Bacteriology, Mycology and Immunology, Faculty of Veterinary Medicine, University of Sadat City, \\ Sadat City, Egypt
}

\begin{abstract}
Foodborne pathogens have the main concern in public health and food safety. Bacillus cereus food poisoning is one of the most important foodborne pathogens worldwide. In the present study, a total of 200 random beef product samples were collected from different supermarkets located at Menofia and Cairo governorates were examined for the presence of $B$. cereus. In addition, the presence of some virulence encoding genes was evaluated using Multiplex PCR. Finally, the antibiogram testing was conveyed to illustrate the resistance pattern of the confirmed B. cereus. The data showed that B. cereus was recovered from $22.5 \%, 30 \%, 25 \%, 37.5 \%$ and $15 \%$ of the minced meat, burger, sausage, kofta, and luncheon respectively. Among the 20 examined isolates 18/20 (90\%) were harbor hblC enterotoxin encoding gene compared with 20/20 (100) were have $c y t K$ enterotoxin encoding gene. The isolated strains of $B$. cereus were resistant to penicillin $G$ and sensitive to oxacillin, clindamycin, vancomycin, erythromycin, gentamicin, ciprofloxacin, and ceftriaxone. In all, the obtained data showed the importance of emerging B. cereus in disease control and prevention programs, and in regular clinical and food quality control laboratories in Egypt.
\end{abstract}

Keywords: Antimicrobial susceptibility, Bacillus cereus, Beef products, Multiplex PCR, Virulence genes.

\section{Introduction}

Processed beef products such as minced meat, kofta, sausage, burger, and luncheon are gaining common popularity as easily quick prepared meat meals that can solve the problem of the high price fresh meat shortage which is not within the reach of large numbers of lowincome families. The contamination of these beef products with the foodborne pathogens is still the main worry for public health, amongst contamination with $B$. cereus is one of the most important foodborne pathogens causing food poisoning among the food consumers all-inclusive.

B. cereus is an aerobic spore-forming Gram-positive bacterium normally disseminated in the environment. It is usually isolated from the soil, plant materials, raw meat and processed meat products (Carlin $\mathrm{F}$ et al., 2010; Ceuppens et al., 2013). Schedule identification of $B$. cereus is generally comprised isolation on selective media, revealing of motility, hemolysis prototype on blood agar, and acidification of glucose (Stenfors Arnesen et al., 2008).

Although B. cereus is implicated in many foodborne illness outbreaks in many countries worldwide, however only a few cases are reported because the symptoms are mostly similar to Staphylococcus aureus and Clostridium perfringens food poisoning (Stenfors Arnesen et al., 2008; Bottone, 2010; Bennett et al.,
2013). B. cereus has been incriminated as a cause of two types of food poisoning, emetic and diarrheal syndromes (Drobniewski, 1993).

The pathogenesis of $B$. cereus-induced food poisoning is mostly still indistinct. The microorganism conveys an expansive number of potentially toxic components, including hemolysins, phospholipases, and proteases (Drobniewski, 1993; Beecher, 2001) nevertheless, the precise role of some is still ambiguous. The emetic and the diarrheal syndromes are still the foremost worries for the public health apprehension and the full appreciative of their pathogenesis is imperative. These syndromes are mainly manifested via the release of two core toxins, a heat-labile diarrheal enterotoxin, and heat- stable emetic enterotoxin (Stenfors Arnesen et al., 2008).

The diarrheal syndrome manifested via the release of one or three diarrheal enterotoxins: the tripartite toxins hemolysin BL (HBL) and non-hemolytic enterotoxin (Nhe), the two forms of cytotoxin K (cytK-1 and cytK2) and possibly enterotoxin $T$ and enterotoxin FM (Moravek et al., 2006). HBL, a three-components toxin, that is encoded by $h b l D$ and $h b l C$ genes respectively, and a binding component $\mathrm{B}$ encoded by hblA gene. The presence of all three components is necessary for the toxin activity (Lindback and Granum, 2006).

*Corresponding Author: Reda Tarabees. Department of Food Hygiene and Control, Faculty of Veterinary Medicine, University 
The deceptive of $B$. cereus induced food poisoning symptoms and the lack of the clear-cut surveillance statistics in Egypt. This makes the indulgent of the pathogenesis of $B$. cereus food poisoning confusing. Therefore, the current study was undertaken to estimate the incidence of toxigenic $B$. cereus in some beef products collected at the retail level in Egypt using PCR. Additionally, the antibiotic resistance pattern of $20 \mathrm{~B}$. cereus isolates was assessed using disc infusion method.

\section{Sampling}

\section{Material and Methods}

A total of 200 beef product samples (40 each of minced meat, burger, sausage, kofta, and luncheon) were collected from different supermarkets located at Menofia and Cairo governorates and examined bacteriologically. The presence of toxigenic $B$. cereus was confirmed using PCR based on the presence of virulence encoding genes.

\section{Preparation of samples}

The collected samples were transferred instantly under full aseptic conditions for bacteriological isolation and identification of $B$. cereus. Briefly, 25 grams of each product were transferred to $225 \mathrm{ml}$ of $0.1 \%$ sterile buffered peptone water (Oxoid, UK), then stomached for 2 minutes to provide a homogenate. The homogenate was heat-treated at $80^{\circ} \mathrm{C}$ for 10 minutes to kill all the vegetative bacteria and recover of the Bacillus spores (Rahimi et al., 2013). One $\mathrm{ml}$ of the original dilution transferred to a sterile tube containing $9 \mathrm{ml}$ of sterile buffered peptone and incubated at $34^{\circ} \mathrm{C}$ for $24 \mathrm{hrs}$ as a primary enrichment.

\section{Isolation and characterization of Bacillus cereus}

The bottles showed turbidity as an indication of $B$. cereus growth were streaked over a dry surface of Bacillus cereus selective agar medium (Oxoid, UK) by a bent glass rod and the plates were incubated at $30^{\circ} \mathrm{C}$ for 24-48 hrs. Suspected typical colonies were later picked up onto sheep blood agar (Oxoid, UK) and incubated at $34^{\circ} \mathrm{C}$ for $24 \mathrm{hrs}$ to observe hemolysis (Tallent et al., 2012).

Typical colonies of $B$. cereus that showed $\beta$ hemolysis were further identified based on the biochemical activities (Holbook and Anderson, 1980; Bottone, 2010; Tallent et al., 2012).

Genotypic characterization of B. cereus enterotoxins genes hblC and cytK

The multiplex PCR was carried out according to Ngamwongsatit et al. (2008). The PCR reactions containing 12.5 $\mu \mathrm{l}$ PCR Master Mix, $1 \mu$ l of each primer ( $0.4 \mu \mathrm{M} h l b \mathrm{C}$ and $0.2 \mu \mathrm{M} c y t \mathrm{~K}$ as final concentration), of $5 \mu \mathrm{l}$ of DNA templates and RNase-free water was added to a final volume of $25 \mu \mathrm{l}$. The PCR conditions were, $94{ }^{\circ} \mathrm{C} / 5 \mathrm{~min}$; 30 cycles of $\left(94^{\circ} \mathrm{C}\right.$ for $45 \mathrm{sec}$, annealing at $54-56^{\circ} \mathrm{C}$ for $1 \mathrm{~min}$ in case of $\mathrm{hblC}$ and at $58^{\circ} \mathrm{C}$ in case of $c y t \mathrm{~K}$, elongation at $72^{\circ} \mathrm{C}$ for $2 \mathrm{~min}$ ) followed by $72^{\circ} \mathrm{C}$ for $5 \mathrm{~min} .94^{\circ} \mathrm{C}$ for $45 \mathrm{sec}$, annealing at 54 and $56^{\circ} \mathrm{C}$ for $1 \mathrm{~min}$ in case of $h b l \mathrm{C}$ and at $58^{\circ} \mathrm{C}$ in case of $c y t \mathrm{~K}$, elongation at $72^{\circ} \mathrm{C}$ for $2 \mathrm{~min}$ and final extension at $72^{\circ} \mathrm{C}$ for $5 \mathrm{~min}$. The products of PCR were separated by electrophoresis on $1.5 \%$ agarose gel (AppliChem, Germany) to determine the fragment sizes. The nucleotides sequences of the primers are shown in the Table 1.

\section{Antimicrobial susceptibility test}

The antibiotic susceptibility testing was performed using the disc diffusion method (Chon et al., 2012). All the isolates were grown in brain heart infusion broth (Oxoid) for $18 \mathrm{hrs}$ at $34^{\circ} \mathrm{C}$ and then spread on MuellerHinton agar (Oxoid, UK) and left for 15 minutes. Then, eight commercial antibiotic discs (Oxoid, UK) were used: penicillin (10 units), oxacillin $(1.0 \mathrm{mg} / \mathrm{ml})$ vancomycin $(30 \mathrm{mg} / \mathrm{m})$, clindamycin $(2.0 \mathrm{mg} / \mathrm{ml})$, erythromycin $(15 \mathrm{mg} / \mathrm{ml})$, gentamicin $(10 \mathrm{mg} / \mathrm{ml})$, Ciprofloxacin $(5 \mu \mathrm{g})$ and Ceftriaxone $(30 \mu \mathrm{g})$, and the plates were then incubated at $37{ }^{\circ} \mathrm{C}$ for $18-24 \mathrm{hrs}$ (Chon et al., 2012).

\section{Results}

Prevalence of B. cereus in the examined beef products The data presented in Table 2 showed the prevalence rate of $B$. cereus in the examined beef products. Among the examined beef products, only 52 out of 200 (26\%) were positive for $B$. cereus. The highest prevalence rate was recorded in case of beef kofta 15/40 (37.5\%), while the lowest rate was in case of beef luncheon $6 / 40$ $(15 \%)$.

\section{Genotypic characterization of enterotoxigenic genes using Multiplex PCR}

The data obtained in Table 3 demonstrated the incidence rate of the $h b l C$ and $c y t K$ enterotoxigenic genes in the examined $B$. cereus isolates. Among the examined isolates, $18 / 20(90 \%)$ were harbor $h b l C$ enterotoxin encoding gene compared with 20/20 (100\%) were found to have $c y t K$ enterotoxin encoding gene and exhibited a specific band size (Fig. 1).

\section{Antibiotic sensitivity testing}

The data presented in Table 4 showed the antibiotic resistance pattern of the examined B. cereus isolates. A total of 51 isolates were tested for their antibiotic sensitivity prototype against 8 commercial antibiotic discs. The data demonstrated that all the isolates $(51 / 51)$ were resistant to penicillin $\mathrm{G}(100 \%)$ and sensitive to other antibiotics 51/51 (100\%).

\section{Discussion}

Contamination of meat products with toxigenic $B$ cereus is one of the underestimated foodborne illness worldwide (Ceuppens et al. 2013). In Egypt, there is no accurate surveillance data about the numbers of $B$. cereus induced food poisoning cases. The lack of accurate data may be because of the resemblance of the symptoms with the other foodborne pathogens (Normanno et al., 2007). 
Table 1. Primers nucleotides sequences used for multiplex PCR amplification of B. cereus entrotoxins genes.

\begin{tabular}{|c|c|c|c|c|c|c|}
\hline Target gene & Primer & Size in bp & Primer sequence $\left(5^{\prime}-3^{\prime}\right)$ & $\mathrm{T}^{\circ} \mathrm{C}$ & Product size in bp & $\operatorname{conc}(\mu \mathrm{M})$ \\
\hline \multirow{2}{*}{$h b l \mathrm{C}$} & FHblC & 19 & CCTATCAATACTCTCGCAA & 54 & \multirow{2}{*}{695} & \multirow{2}{*}{0.4} \\
\hline & RHblC & 20 & TTTCCTTTGTTATACGCTGC & 56 & & \\
\hline \multirow{2}{*}{$\operatorname{cyt} \mathrm{K}$} & FCytK & 20 & CGACGTCACAAGTTGTAACA & 58 & \multirow{2}{*}{565} & \multirow{2}{*}{0.2} \\
\hline & R2CytK & 20 & CGTGTGTAAATACCCCAGTT & 58 & & \\
\hline
\end{tabular}

Table 2. Prevalence rate of B. cereus in the examined beef products (40 of each).

\begin{tabular}{lcccc}
\hline \multirow{2}{*}{ Beef products } & \multicolumn{2}{c}{ Positive sample } & \multicolumn{2}{c}{ Negative sample } \\
\cline { 2 - 5 } & No & $\%$ & No & $\%$ \\
\hline Minced meat & 9 & 22.5 & 31 & 77.5 \\
Beef burger & 12 & 30 & 28 & 70 \\
Beef sausage & 10 & 25 & 30 & 75 \\
Beef kofta & 15 & 37.5 & 25 & 62.5 \\
Beef luncheon & 6 & 15 & 34 & 85 \\
Total & 52 & 26 & 148 & 74 \\
\hline Minced meat & No & $\%$ & No & $\%$ \\
\hline
\end{tabular}

Table 3. Molecular detection of enterotoxigenic genes of $B$. cereus isolated from examined samples.

\begin{tabular}{lccc}
\hline Target gene & $\begin{array}{c}\text { No of examined } \\
\text { isolate }\end{array}$ & $\begin{array}{c}\text { Positive } \\
\text { isolate }\end{array}$ & $\%$ \\
\hline$h b l \mathrm{C}$ & 20 & 18 & 90 \\
$c y t \mathrm{~K}$ & 20 & 20 & 100 \\
\hline
\end{tabular}

Table 4. Antibiotics resistant of $B$. cereus isolated beef products $(n=51)$.

\begin{tabular}{lccc}
\hline $\begin{array}{l}\text { Antibiotic } \\
\text { tested }\end{array}$ & Resistant & Intermediate & Sensitive \\
\hline Penicillin G & $51(100.0)$ & $0(0.0)$ & $0(0.0)$ \\
Oxacillin & $0(0.0)$ & $0(0.0)$ & $51(100.0)$ \\
\hline Vancomycin & $0(0.0)$ & $0(0.0)$ & $51(100.0)$ \\
Clindamycin & $0(0.0)$ & $0(0.0)$ & $51(100.0)$ \\
Erythromycin & $0(0.0)$ & $0(0.0)$ & $51(100.0)$ \\
Gentamicin & $0(0.0)$ & $0(0.0)$ & $51(100.0)$ \\
Ciprofloxacin & $0(0.0)$ & $0(0.0)$ & $51(100.0)$ \\
Ceftriaxone & $0(0.0)$ & $0(0.0)$ & $51(100.0)$ \\
\hline
\end{tabular}

The contamination of beef products probably occurred during handling and preparation or post-processing contamination. In addition, keeping the products unrefrigerated for several hours enhances the multiplication of $B$. cereus and hence the liberation of enterotoxin. The study herein was aimed to estimate the accurate incidence rate of toxigenic $B$. cereus and its antibiotic susceptibility pattern in some beef products collected from different localities in Egypt. The data obtained will probably highlight the emergence of $B$. cereus as a serious underestimated cause of foodborne illness and will help in understanding its pathogenesis.

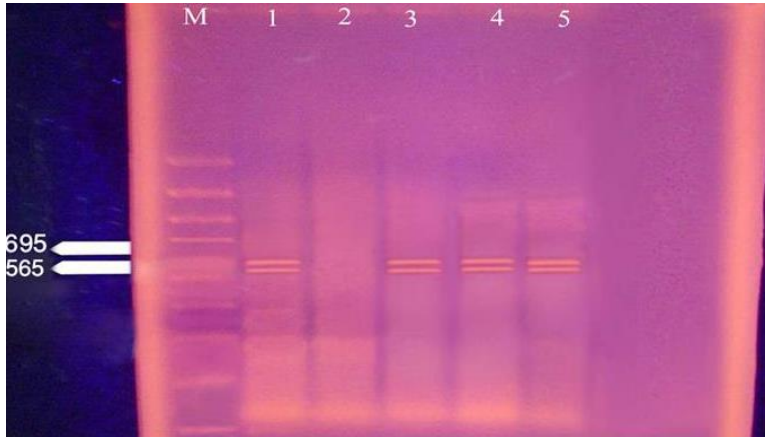

Fig. 1. Genotypic characterization of enterotoxins encoding genes $h h l \mathrm{C}$ and $c y t \mathrm{~K}$ using specific primers sets. Lane (M): DNA Ladder (10bp); Lane (1): positive control; Lane (2): negative control; Lanes (3-5) Bacillus cereus exhibited a specific band size of $595 \mathrm{bp}$ and $565 \mathrm{bp}$ representing $\mathrm{hblC}$ and cyt $\mathrm{K}$ enterotoxin-encoding genes respectively.

The data obtained in the Table 2 demonstrated that the highest incidence rate was recorded in beef kofta and the lowest was in the case of minced meat. This outcome is similar to that obtained by Mohamed and Ghanyem (2015), and higher compared with that obtained by Heikal et al. (2006). Conversely, this result is lower than the result obtained by Eid et al. (2008).

Processed ready to eat beef products are considered the main source of infection with $B$. cereus and more caution need to be taken in order to minimize the contamination of such products. The selection of fresh and clean flesh, decontamination of the mincing machine, grinders, equipment and knives used in the processing of such products will auspiciously decrease the incidence of $B$ cereus foodborne illness cases among the consumers (FDA, 2012; Torky, 1995, 2004). The higher incidence rate of the $B$. cereus in kofta and minced meat in comparison with luncheon can be explained as luncheon during the processing steps the product was subjected to a high temperature that significantly decreases the number of Bacillus spores (Torky, 1995).

Additionally, during the processing of minced meat and kofta, additives, seasoning, and spices were added, these additives are considered a potential risk factor can increase the number of Bacillus spores and hence magnitude the incidence of food poisoning. Therefore more consideration should be taken during processing of raw meat and kofta, and only use additives from a trustful source. Moreover, these additives should be regularly tested for the presence of Bacillus spores. 
Schedule examination of beef products for the presence of Bacillus spores is requisite. Isolation and identification of Bacillus using traditional methods (culturing on selective media and biochemical testing of the confirmed isolates) is still the key element for the confirmation of the infection. The severity of infection with Bacillus is conveyed via the liberation of an array of virulence encoding genes.

Multiplex PCR has emerged as the fast and reliable technique for the confirmation of enterotoxigenic $B$. cereus (Guinebretiere et al., 2006; Ombui et al., 2008). Recently, Ngamwongsatit et al. (2008) have developed and evaluated a group of newly efficient primers used for detection of the genes encoding enterotoxin production in $100 \%$ of the tested B. cereus and $B$. thuringensis strains assuming that, the presence of either gene is an indication for the presence of the whole operon (Ngamwongsatit et al., 2008).

In the current work, the existence of the enterotoxinencoding genes $h b l \mathrm{C}$ and $c y t \mathrm{~K}$ was assessed in $20 \mathrm{~B}$. cereus isolates using specific primers sets that previously approved by Ngamwongsatit et al. (2008). The data presented in Table 3 and Figure 1 demonstrated that 18 isolates $(90 \%)$ and 20 isolates $(100 \%)$ were positive for $h b l \mathrm{C}$ and $c y t \mathrm{~K}$ gene, respectively. This outcome is in accordance with that obtained previously obtained by Awny et al. (2010). Collectively, emerging of the multiplex PCR as a rapid technique for the affirmation of toxigenic $B$. cereus in food will probably command the pathogenesis of $B$. cereus induced-food poisoning in Egypt.

A total of $51 \mathrm{~B}$. cereus isolates were further tested for their antimicrobial susceptibility (Table 4). All the tested isolates were resistant to penicillin $G$, whereas sensitive to oxacillin, clindamycin, vancomycin, erythromycin, gentamicin, ciprofloxacin, and ceftriaxone. The data obtained herein with the others (Fenselau et al., 2008; Organji et al., 2015; Jawad et al., 2016) showed that $B$. cereus has a broad range of antibiotic susceptibility and validate the resistance to penicillin $G$ by comparing to susceptibility to clindamycin, vancomycin, and erythromycin.

\section{Conclusion}

From the obtained data, many conclusions could be drawn, contamination of beef products with $B$. cereus increase the potential of foodborne infections among the consumers. The cleanliness of the equipment, processing machines, knives, and only use additives from trustful sources are measures significantly will minimize the infection with Bacillus spores. Schedule antibiotic susceptibility testing of $B$. cereus isolates recovered from beef products will guide choosing the appropriate antibiotic. Also, the data authenticate the significance of counting $B$. cereus in disease control and prevention programs, and in regular clinical and food quality control laboratories in Egypt.

\section{Conflict of interest}

The authors declare that there is no conflict of interest.

\section{References}

Awny, N.M., Abou Zeid, A.A.M. and Abdo, A.M. 2010. Prevalence of toxigenic bacteria in some Egyptian food. The Fifth Scientific Environmental Conference, Zagazig University.

Beecher, D.J. 2001. The Bacillus cereus group. In P. C. B. Turnbull ed., Gastro-intestinal infections: toxinassociated diseases. Academic Press, London, pp: 1161-1190.

Bennett, S.D., Walsh, K.A. and Gould, L.H. 2013. Foodborne disease outbreaks caused by Bacillus cereus, Clostridium perfringens, and Staphylococcus aureus-then United States, 19982008. Clin. Infect. Dis. 57(3), 425-433.

Bottone, E.J. 2010. Bacillus cereus, a volatile human pathogen. Clin. Microbiol. Rev 23(2), 382-398.

Carlin, F., Brillard, J., Broussole, V., Clavel, T., Duport, C., Jobin, M., Guinebretière, M.H., Auger, S., Sorokine, A. and Nguyen-The, C. 2010. Adaptation of Bacillus cereus, a ubiquitous worldwide-distributed foodborne pathogen, to a changing environment. Food Res. Int. 43(7), 18851894.

Ceuppens, S., Boon, N. and Uyttendaele, M. 2013. Diversity of Bacillus cereus group strains is reflected in their broad range of pathogenicity and diverse ecological lifestyles. FEMS Microbiol. Ecol. 84(3), 433-450.

Chon, J. W., Kim, J. H., Lee, S. J., Hyeon, J. Y., Song, K.Y. and Park, C. and Seo, K.H. 2012. Prevalence, phenotypic traits and molecular characterization of emetic toxin-producing Bacillus cereus strains isolated from human stools in Korea. J. Appl. Microbiol. 112, 1042-1049.

Drobniewski, F.A. 1993. Bacillus cereus and related species. Clin. Microbiol. Rev. 6(4), 324-338.

Eid, A.M., Eleiwa, N.Z.H. and Zaky, E.M.S. 2008. Prevalence of Bacillus cereus in some ready-to-eat meat products. $9^{\text {th }}$ Vet. Med. Zag. Conference. 2022 August, Port-Said.

Fenselau, C., Havey, C., Teerakulkittipong, N., Swatkoski, S., Laine, O. and Edwards, N. 2008. Identification of B-lactamase in antibiotic-resistant Bacillus cereus spores. Appl. Environ. Microbiol. 74, 904-906.

Food and Drug Administration (FDA). 2012. Bacillus cereus. Downloaded from http://www.fda.gov/ Food/Science Research/Laboratory Methods/ Bacteriological Analytical Manual BAM/ ucm 070875.

Guinebretiere, M., Fagerlund, A., Granum, P.E. and Nguyen, C. 2006. Rapid discrimination of cytK-1 and cytK-2 genes in Bacillus cereus strains by a 
novel PCR system. FEMS Microbiol. Lett. 59(1), 74-80.

Heikal, G.I., Khafagi, N.I.M. and Mostafa, N.Y.2006. Bacillus cereus in some ready to cook meat products. Benha Vet. Med. J. 17(2), 343-350.

Holbook, R. and Anderson, J.M. 1980. An improved selective and diagnostic medium for isolation and enumeration of Bacillus cereus in foods. Can. J. Microbiol. 26(7), 254-261.

Jawad, N., Abd Mutalib, S. and Abdullah, A. 2016. Antimicrobial resistance pattern of Bacillus cereus strains Isolated from fried rice samples. Int. J. Chem.Tech. Res. 8(1), 160-167.

Lindback, T. and Granum, P.E. 2006. Detection and Purification of Bacillus cereus Enterotoxins. In: Adley, C.C. Food-Borne Pathogens: Methods and Protocols. Totawa, Humana Press, pp: 15-24.

Mohamed, W.S. and Ghanyem, H.R. 2015. Effect of some preservative on Bacillus cereus isolated from some meat products. Assiut Vet. Med. J. 61(146), 1-7.

Moravek, M., Dietrich, R., Buerk, C., Broussolle, V., Guinebretiere, M.H., Granum, P.E., Nguyen-The, C. and Martlbauer, E. 2006. Determination of the toxic potential of Bacillus cereus isolates by quantitative enterotoxin analyses. FEMS Microbiol. Lett. 257(2), 293-298.

Ngamwongsatit, P., Buasri, W., Pianariyanon, P., Pulsrikarn, C., Ohba, M., Assavanig, A. and Panbangred, W. 2008. Broad distribution of enterotoxins genes (hblCDA, nheABC, cytK and entFm) among Bacillus thuringiensis and Bacillus cereus as shown by novel primers. Int. J. Food Microbiol. 121(3), 352-356.

Normanno, G., La Salandra, G., Dambrosio, A., Quaglia, N.C., Corrente, M., Parisi, A., Santagada,
G., Firinu, A., Crisetti, E. and Celano, G.V. 2007. Occurrence, characterization and antimicrobial resistance of enterotoxigenic Staphylococcus aureus isolated from meat and dairy products. Int. J. Food Microbiol. 115(3), 290-296.

Ombui, J.N., Gitahi, N. and Gicheru, M. 2008. Direct detection of Bacillus cereus enterotoxin genes in food by multiplex polymerase chain reaction. Int. J. Integ. Biol. 2(3), 172-181

Organji, S.R., Abulreesh, H.H., Elbanna, K., Osman, O.E.H. and Khider, M. 2015. Occurrence and characterization of toxigenic Bacillus cereus in food and infant feces. Asian Pac. J. Trop. Biomed. 5(7), 515-520.

Rahimi, E., Abdos, F., Momtaz, H., Baghbadorani, Z.T. and Jalali, M. 2013. Bacillus cereus in infant foods: prevalence study and distribution of enterotoxigenic virulence factors in Isfahan Province, Iran. Sci. World J. doi:10.1155/2013/292571.

Stenfors Arnesen, L.P., Fagerlund, A. and Granum, P.E. 2008. From soil to gut: Bacillus cereus and its food poisoning toxins. FEMS Microbiol. Rev. 32(4), 579-606.

Tallent, S.M., Rhodehamel, E.J., Harmon, S.M. and Bennett, R.W. 2012. Bacillus cereus. In: Bacteriological analytical manual. USA: US Food and Drug Administration; 2012. Available at: https://www.fda.gov/Food/FoodScienceResearch/L aboratoryMethods/ucm070875.htm

Torky, A.A.S. 1995. Bactero- toxological studies of Bacillus cereus in meat products. Master Thesis, Meat and Milk Hygiene, Cairo, Cairo University.

Torky, A.A.S. 2004. Trials for inhibition of some food poisoning microorganism in meat products. $\mathrm{PhD}$ thesis, Meat and Milk Hygiene. Cairo, Cairo University. 